\title{
AHP APPROACH APPLIED TO MULTI-CRITERIA DECISIONS IN ENVIRONMENTAL FRAGILITY MAPPING
}

\author{
Luciano Cavalcante de Jesus França ${ }^{1 *}$, Danielle Piuzana Mucida ${ }^{2}$, Reynaldo Campos Santana ${ }^{3}$, Marcelino Santos \\ de Morais ${ }^{4}$, Lucas Rezende Gomide ${ }^{5}$, Carlos Valdir de Meneses Bateira ${ }^{6}$ \\ $1,5 *$ Federal University of Lavras, Department of Forest Science, Graduate Program in Forest Engineering, Lavras, Minas Gerais, Brazil - \\ lucianocjfranca@gmail.com \\ ${ }^{2}$ Federal University of the Jequitinhonha and Mucuri Valleys, Department of Geography, Graduate Program in Forest Sciences, Diamantina, \\ Minas Gerais, Brazil - dpiuzana@yahoo.com.br. \\ ${ }^{3}$ Federal University of the Jequitinhonha and Mucuri Valleys, Department of Forest Engineering, Graduate Program in Forest Sciences, \\ Diamantina, Minas Gerais, Brazil - silviculturaufvjm@yahoo.com.br. \\ ${ }^{4}$ Federal University of the Jequitinhonha and Mucuri Valleys, Department of Geography, Diamantina, Minas Gerais, Brazil - \\ morais.marcelino@gmail.com. \\ ${ }^{6}$ University of Porto, Department of Geography, Porto, Portugal - carlosbateira@ gmail.com.
}

Received for publication: 25/02/2019 -Accepted for publication: 23/04/2020

\begin{abstract}
Resumo
Método AHP aplicado a decisão multicritério em mapeamentos de fragilidade ambiental. As ferramentas do Sistema de Informações Geográficas, combinadas com métodos matemáticos para investigações científicas geoespaciais complexas, são essenciais para o zoneamento ambiental. Dentre essas ferramentas, os modelos de fragilidade ambiental avaliam critérios relacionados aos atributos físicos da paisagem para garantir a multidisciplinaridade dos planos de informações utilizados em um estudo. No entanto, são levantadas questões sobre a prioridade atribuída a cada critério ou fator ambiental dentro de um modelo de análise de múltiplos critérios. Nesse sentido, o processo analítico hierárquico é outro modelo matemático usado na teoria da decisão, que classifica os critérios hierarquicamente. Este estudo tem como objetivo utilizar o método AHP como uma ferramenta para apoiar a tomada de decisão multicritério aplicada ao mapeamento de fragilidade ambiental, usando a Bacia Hidrográfica do rio Jequitinhonha, Minas Gerais, Brasil, como um estudo de caso. A aplicação do método AHP forneceu uma hierarquia de cinco critérios ambientais importantes para o mapeamento da fragilidade ambiental. O uso do AHP permitiu modelar avaliações empíricas em resultados matematicamente consistentes, para proporcionar uma melhor concisão nos processos geoespaciais. Portanto, é um método adequado para minimizar a subjetividade no planejamento ambiental e territorial. Também pode ajudar no gerenciamento de zonas prioritárias para conservação, preservação ou restauração ecológica.

Palavras-chave: Planejamento ambiental, Manejo de ecossistemas, Sistemas de informações geográficas,
\end{abstract} Pesquisa operacional.

\begin{abstract}
Geographic Information System tools, combined with mathematical methods for complex geospatial scientific investigations, are essential for environmental zoning. Among these tools, environmental fragility models evaluate criteria related to the physical attributes of the landscape to ensure multi-disciplinarity of the information plans used in a study. However, questions are raised on the priority allotted to each criterion or environmental factor within a multi-criteria analysis model. In this sense, the analytic hierarchy process is another mathematical model that is used in decision theory, which sorts criteria hierarchically. This study aims to use the AHP method as a tool to support multi-criteria decision making as applied to environmental fragility mapping, using the Jequitinhonha River Basin, Minas Gerais, Brazil, as a case study. The application of the AHP method provided a hierarchy of five important environmental criteria for the environmental fragility mapping. The use of AHP allowed the modeling of empirical evaluations in mathematically consistent results, to provide better conciseness in geospatial processes. Therefore, it is an adequate method to minimize subjectivity in environmental and territorial planning. It can also help the management of priority zones for conservation, preservation, or ecological restoration.

Keywords: Environmental planning, Management of ecosystems, Geographic information systems, Operational research.
\end{abstract}

\section{INTRODUCTION}

The demand for strategies that provide for significant time saving, improved productivity, and lower costs in the analyses of processes for environmental planning, land, and forest management is increasing. In this sense, the search is for tools integrated with the Geographic Information System (GIS) and the use of geoprocessing products that aid assertive decision-making. 
Environmental assessments can be obtained by mapping potential environmental fragility, which indicates the susceptibility of natural spaces to the occurrence of natural or induced degradation processes. Models of analysis of environmental fragility use simultaneous criteria (n factors) of the analyzed area, which are represented by layers of geographic data, known as multi-criteria evaluation (MCE) in the GIS environment. Usually, a multi-disciplinary team supports these analyses (PADILHA et al., 2014).

Methodology based on the slope of the terrain for determining environmental fragility, is the most widely used in scientific environmental research (ROSS, 1994). In sequence, Rosa and Ross (1999) used map algebra (soil classes, geomorphology, vegetation cover, and declivity maps) in a GIS environment to generate potential and emergent environmental fragility maps. However, investigations have been adapted over the years, aiming to obtain more realistic results and to include new criteria (GONÇALVES et al., 2011; PADILHA et al., 2014; JUNIOR et al., 2015).

Analyses of environmental fragility developed by map algebra vary from a standard scale of fragility weights from 1 (low) to 5 (extremely high) (ROSS, 1994). However, the results can also be associated with uncertainties caused by human judgment. Thus, a hierarchy of importance for each environmental parameter, should be considered in the analysis to increase the reliability of the method; this is provided by the analytic hierarchy process (AHP). The method requires mathematical operational weighting by a multi-criteria decision support model and enables verification of inconsistencies (SAATY, 1980), and has been used in several GIS studies (VALENTE, VETTORAZZI, 2009; SAHOO et al., 2016; KUNDU et al., 2017).

The application of AHP is for the assignment of weights for decision-making and prioritization of areas and problems with multiple criteria (KHAIRA; DWIVEDI, 2018). Additionally, studies have used the method to convert empirical data based on land use into mathematical models (SANTOS; CRUZ, 2013; KUNDU et al., 2017; MORANDI et al., 2020).

Research based on decision-making processes should adopt logical sequences of procedures. The definition and delimitation of the area, the approach to the analysis, and identification of factors of interest lend potential risks or benefits to the method. The elements represent uncertainties in the decision process, defined as: local or global changes; the physical and biotic environment; environmental degradation; and anthropic actions. The solution to the problem is a result of the efficiency of the criteria and procedures adopted (VALENTE; VETTORAZZI, 2009).

The AHP consists of a square matrix $n \times n$, where the rows and columns correspond to the criteria analyzed for the problem in question. Thus, each matrix cell value represents the relative importance of the row versus the column (MIARA; OKA-FIORI, 2007). In the end, the AHP analysis generates a consistent index (CI) and consistent ratio (CR), calculated to analyze, determine, and decide the various criteria that influence decision making, consistently justifying the choice and allowing for adjustments to be repeated in the comparison (SANTOS; CRUZ, 2013; MARTINS et al., 2014).

In this context, the hypothesis of this study assumes that the multi-criteria analysis from Ross (1994) integrated with the AHP methodology improves decision-making and the definition of the relationships of environmental fragility in the context of watersheds. The objective of this study was to apply the AHP as a tool to support multi-criteria decision-making in mapping potential environmental fragility as well as to verify the consistency of the structured decision process for a GIS platform.

\section{MATERIALS AND METHODS}

\section{Analytic Hierarchy Process (AHP)}

Figure 1 synthesizes the methodological procedures used in this study. Hierarchy creation for decisions from the AHP is based on the formulation of the problem at a superior level. Subsequently, the criteria used to evaluate the alternatives are determined and classified in hierarchical order. The process of creating a hierarchy is completed with the placement of decision alternatives at a hierarchical level of relevance (Figure 2). 


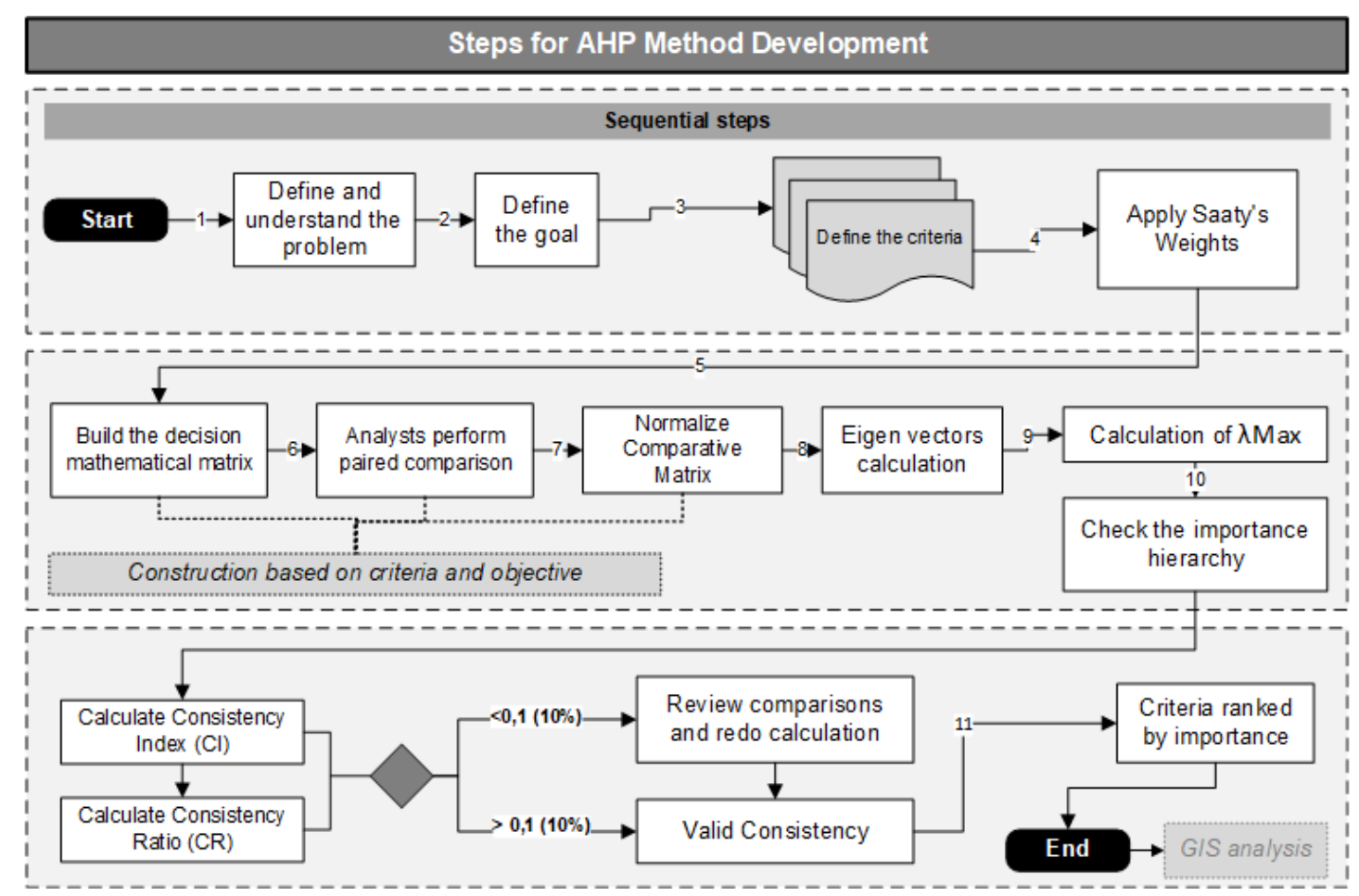

Figure 1. Steps and procedures for AHP method replication.

Figura 1. Etapas e procedimentos para replicação do método AHP.

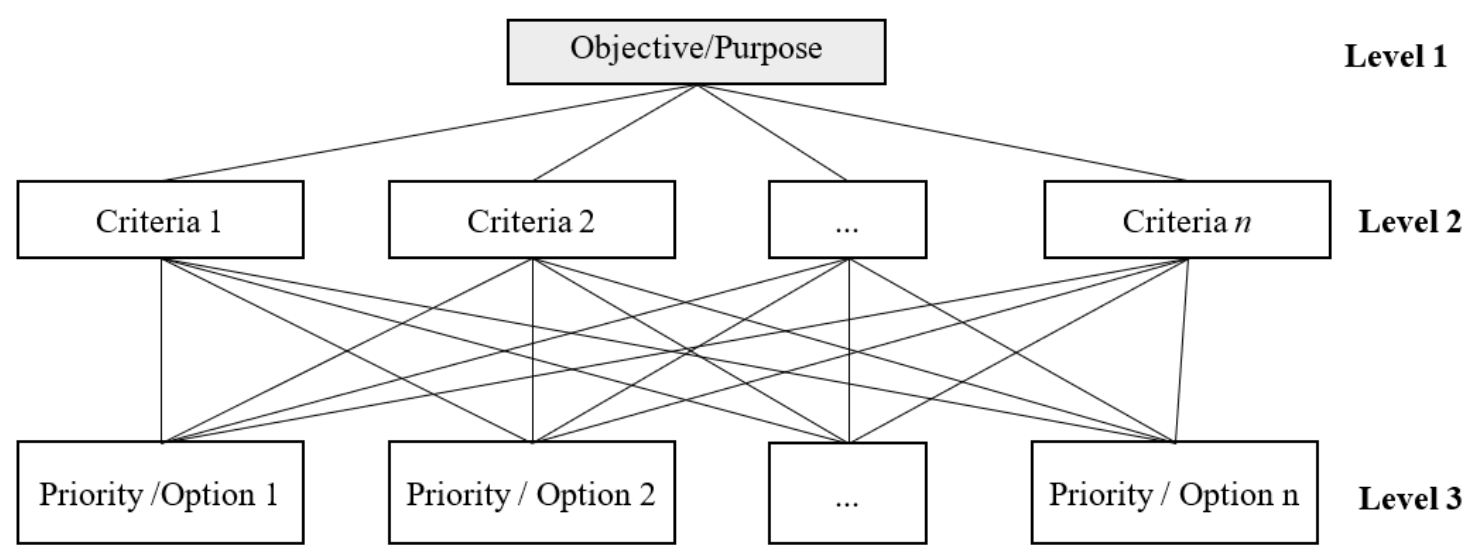

Figure 2. Fundamental illustration of the AHP decision hierarchy composed of an objective/purpose, criteria, and options (Adapted from Morandi et al., 2020).

Figura 2. Ilustração fundamental da hierarquia de decisão do AHP composta de um objetivo/finalidade, critérios e opções (Adaptado de Morandi et al., 2020).

The AHP method, according to Saaty (2005), consists of:

(i) Definition of the problem and objective to be achieved - it is necessary to establish the critical aim of the analysis, which in this case is the definition of environmental fragility.

(ii) Structuring the criteria in a hierarchy with the help of the decision-makers - which in this study are, terrain slope, soil classes, rainfall, geological domains, and drainage hierarchy;

(iii) Construction of the pair-wise comparison matrix according to the expression below: 


$$
\mathrm{A}=\left[a_{i j}\right]=\left[\begin{array}{cccc}
1 & a_{12} & \cdots & a_{1 n} \\
1 / a_{21} & 1 & \cdots & a_{2 n} \\
\vdots & \vdots & \ddots & \vdots \\
1 / a_{n 1} & 1 / a_{n 2} & \cdots & 1
\end{array}\right]
$$

Where $i, j=1,2, \ldots, n ; a_{i j}=1$ for $i=j ; a_{i j}=1 / a_{i j}$ for if $\neq j$.

(iv) Attribution of weight to each criterion to obtain the hierarchical degree of particular importance, using the matrices of the analysts linked to the study.

An analysis of the five information plans of the area was carried out to generate the importance weights. The map algebra of the GIS platform uses the weights assigned to the final analysis equation of environmental fragility. This method applies to situations involving subjective judgments with quantitative and qualitative data. The development of steps in the AHP was made in the spreadsheets of Excel $^{\mathrm{TM}}$ software.

To define the importance of the factor weights in the decision process, we elaborated a comparison matrix between the criteria according to their relative importance (SAATY, 1980). The values were derived on a continuous scale of 1 (one) to 9 (nine), where 1 (one) indicates that two criteria have "equal" importance until 9 (nine), which implies that one criterion is "extremely" more important than the other (Table 1).

Table 1. The scale of relative importance from the comparison of criteria (adapted from SAATY, 1980).

Tabela 1. Escala referente à importância relativa a partir da comparação de critérios (adaptada de SAATY, 1980).

\begin{tabular}{cccl}
\hline Scale & Evaluation & Reciprocity & \multicolumn{1}{c}{ Description } \\
\hline $\begin{array}{c}\text { Same importance } \\
\text { Moderate Importance }\end{array}$ & 1 & 1 & The two criteria contribute equally to the objective. \\
\hline $\begin{array}{c}\text { Essential or Strong } \\
\text { Importance }\end{array}$ & 5 & $1 / 3$ & $\begin{array}{l}\text { Analysis, experience, and judgment favor one activity } \\
\text { slightly compared to the other: one criterion is slightly } \\
\text { more important than the other. }\end{array}$ \\
\hline $\begin{array}{c}\text { Very Strong } \\
\text { importance }\end{array}$ & 7 & $1 / 5$ & $\begin{array}{l}\text { One criterion is predominant and more critical than the } \\
\text { other. }\end{array}$ \\
\hline $\begin{array}{c}\text { Extremely more } \\
\text { important }\end{array}$ & 9 & $\begin{array}{l}\text { One criterion is very strongly favored over another and } \\
\text { can be demonstrated in practice. }\end{array}$ \\
\hline
\end{tabular}

The AHP requires three assumptions: reciprocity (if $\mathrm{a}_{\mathrm{ij}}=\mathrm{x}$, then $\mathrm{a}_{\mathrm{ji}}=1 / \mathrm{x}$, with $1 / 9 \leq \mathrm{x} \leq 9$ ); homogeneity (if the elements $i$ and $j$ are considered equally important, then $\mathrm{a}_{\mathrm{ij}}=\mathrm{a}_{\mathrm{ji}}=1$, besides that $\mathrm{a}_{\mathrm{i}}=1$ for everything $i$ ); consistency (Consistency Index and Ratio should be $\leq 0,10$, or $10 \%$ ).

We elaborated on a peer-to-peer analysis matrix, and the results gave the weights assigned to each layer. After this step, we calculated the weighted sum (map algebra) of all the factors, based on the results of the mathematical matrix that presented the criteria by hierarchical importance (Table 1). The method requires the numerical and technical evaluation by specialists in different areas, who issue weights to the mathematical matrix.

In this study, we applied the binary correlation from the participatory technique by specialists of the related research lines (geomorphology, geology, pedology, forest engineering, and geoprocessing). We defined the importance levels for the pair-wise comparison matrix based on the scope of the method, besides the bibliographical surveys and field diagnoses carried out in the Jequitinhonha river basin between 2016 and 2017. We suggest that one or more of the below procedural criteria for paired comparison can be used:

- The researcher must weigh the importance scale based on his technical or scientific-academic experience and field diagnoses;

- The researcher can prove that one factor is more vital than the other by utilizing a bibliographical survey;

- Alternatively, a multi-disciplinary team, separately and together, can define the scale that closely approximates reality with field recognition and conduct debates. 
The union of the three options is the most interesting strategy, allowing interdisciplinarity and better coherence in the result. The importance scale table also presents the possibility of using intermediate values $(2,4$, 6 , and 8) when there is no consensus among some items of judgment (SAATY, 1980). Then, the parts must compromise to reach an agreement.

\section{The consistency index (CI) and consistency rate (CR) for AHP}

The AHP method allows us to analyze, determine, and decide the various criteria that influence decisionmaking and, consequently, generate information that helps the decision-maker choose the best of the proposed alternatives based on the criteria analyzed.

For the numerical assignment of the paired analysis, we performed the mathematical operations of the matrices (SAATY, 1980) in four sub-stages:

(i) Calculation of the eigenvector $(w)^{l}$ and main eigenvector $\left(\lambda_{\text {Max }}\right)^{2}$ : The first step is to normalize the prepared pair-wise comparison matrix. As a result, matrix $A=\left[a_{i j}\right]$ is transformed into matrix $B=\left[b_{i j}\right]$. The elements of matrix B were calculated (Eq. 1), where the values of each comparison (cell) are divided by the sum of the referred column:

$$
b_{i j}=\frac{a_{i j}}{\sum_{i=1}^{n} a_{i j}}(\text { Eq. } 1)
$$

The eigenvector $\left(\mathrm{w}=\left[\mathrm{w}_{\mathrm{i}}\right]\right)$, representing the weight of importance of each criterion, is calculated by the arithmetic average from the row of the normalized comparison matrix B:

$$
w_{i}=\frac{\sum_{j=1}^{n} b_{i j}}{n} \quad \text { (Eq. 2) }
$$

We obtained the main eigenvector $\left(\lambda_{\mathrm{Max}}\right)$ by calculating the sum of the product of each criterion comparing with matrix A by the eigenvector (w) of each criterion, dividing the result of that expression by the eigenvector (w). Then, the arithmetic mean is calculated (SANTOS; CRUZ, 2013):

$$
\left.\lambda_{\text {Max }}=\frac{1}{n} \sum_{i=1}^{n} \frac{(A w)_{i}}{w_{i}} \quad \text { (Eq. } 3\right)
$$

where $(\mathrm{Aw}) \mathrm{i}=$ Matrix resulting from the product of the comparison matrix A paired by the matrix of calculating weights $\left(\mathrm{w}_{\mathrm{i}}\right)$, and where $\mathrm{w}_{\mathrm{i}}=$ calculated weights.

(ii) Calculation of the Consistency Index (CI): After the elaboration of the AHP matrix and definition of importance weights of the criteria, it is necessary to verify the inconsistency of the data. This step aims to determine whether the decision-makers were consistent in their considerations. The following equation gives the calculation of the consistency index (Saaty, 2005):

$$
C I=\frac{\lambda_{\operatorname{Max}}-n}{n-1} \quad(\text { Eq. } 4)
$$

where CI: consistency Index; n: number of evaluated criteria; $\lambda_{\text {Max }}$ : main vector of Eigen.

(iii) Calculation of the degree or Consistency Ratio (CR): The CR indicates the consistency of the data for decision-making. Saaty (2005) proposed a consistency ratio (CR) determined by the ratio between the CI and the random consistency index (RI), variable, according to size $\mathrm{n}$ of the sample. The matrix will be consistent if the ratio is $<0.1$ or $10 \%$, as demonstrated by the expression:

$$
C R=\frac{C I}{R I}<0,1 \sim 10 \% \quad(\text { Eq. } 5)
$$

\footnotetext{
${ }^{1}$ The eigenvector $(w)$ represents the contribution of each criterion to the achievement of the goal. The arithmetic mean is calculated for the normalized score of each criterion. The exact calculation of the eigenvector is determined only in specific cases. Most practical cases use this approach to simplify the calculation process, since the difference between the real value and the approximate value is less than $10 \%$ (KOSTLAN, 1990; VARGAS, 2010).

${ }^{2}$ The inconsistency index of the AHP methodology is based on the main eigenvector ( $\lambda \mathrm{Max}$ ) obtained by the sum of the multiplication of each element of eigenvector by the sum of the corresponding column of the comparative matrix (VARGAS, 2010).
}

FLORESTA, Curitiba, PR, v. 50, n. 3, p. 1623 - 1632, jul/set 2020. 
where RI is a constant value and depends on the number of evaluation criteria (Table 2).

Table 2. RI (Random Index) values for matrices of different sizes (SAATY, 2005).

Tabela 2. Valores de IR (Índice Randômico) para matrizes de diferentes tamanhos (SAATY, 2005).

\begin{tabular}{ccccccccccc}
\hline Matrix sizes (n) & $\mathbf{1}$ & $\mathbf{2}$ & $\mathbf{3}$ & $\mathbf{4}$ & $\mathbf{5}$ & $\mathbf{6}$ & $\mathbf{7}$ & $\mathbf{8}$ & $\mathbf{9}$ & $\mathbf{1 0}$ \\
\hline RI Value & 0 & 0 & 0.58 & 0.9 & 1.12 & 1.24 & 1.32 & 1.41 & 1.45 & 1.49 \\
\hline
\end{tabular}

(iv) Data analysis: The degree of consistency is satisfactory when CR values are less than 0.1 (SAATY, 2005). When CR values are higher than $0.1(10 \%)$, the recommendation is to re-evaluate the data collected from the specialists, verifying that there are no misunderstandings or errors during the survey process.

\section{AHP in the Potential Environmental Fragility Equation}

To the potential environmental fragility equation, we applied mapping methods (map algebra) by a weighted overlay on GIS software. We used the spatial analyst tools > map algebra > raster calculator or the following overlay command: Spatial Analyst Tools> Overlay> Weighted Overlay. QGIS software performed the same procedure: Raster > Raster Calculator command. However, it is essential to note that there may be variations of interfaces depending on the version of the software.

The hierarchical weights of importance generated in the AHP are applied to the processing for each of the five (5) evaluated criteria, by the integration of the PEF equation, inserted in a GIS environment:

$$
\mathrm{PEF}=(\mathrm{FD} * \mathrm{X} 1)+(\mathrm{FS} * \mathrm{X} 2)+(\mathrm{FDG} * \mathrm{X} 3)+(\mathrm{FHF} * \mathrm{X} 4)+(\mathrm{FCP} * \mathrm{X} 5) \quad(\mathrm{Eq} .6)
$$

Where PEF = Potential Environmental Fragility FD = Terrain Slope Fragility; FS = Soil Class Fragility; FDG = Geological Domain Fragility; FHF = Drainage Hierarchy Fragility; FCP = Rainfall Fragility; X1 ...5 = Statistical importance weights generated in the AHP method.

\section{RESULTS}

We applied the methodology of the AHP method to plan information from the Jequitinhonha river basin located in the northeast portion of the state of Minas Gerais, Brazil. The Jequitinhonha basin presents landscape units with high heterogeneity, distributed over $70,315 \mathrm{~km}^{2}$, of which $66,319 \mathrm{~km}^{2}$ is in Minas Gerais and $3,996 \mathrm{~km}^{2}$ in the Bahia (IBGE, 1997). It is located between the parallels $15^{\circ} 39^{\prime}$ and $18^{\circ} 36 \mathrm{~S}$, and the meridians $39^{\circ} 50^{\prime}$ and $43^{\circ} 48^{\prime} \mathrm{W}$, with a SW-NE orientation.

We generated the main AHP matrix (Table 3) considering information on the classes of soil, terrain slope, geological domains, rainfall, and drainage hierarchy according to the scale of Saaty (1980). The next step was the procedure with the final matched comparison matrix; the fractional values used to calculate the eigenvector are in parentheses in Table 4.

After the matched comparison matrix was processed, we executed the division between the individual comparison value of each column of table 3 ) by the sum (Total $\Sigma$ ) of the respective columns. Thus, we performed all comparisons of the AHP matrix (an example using Equation 1: Comparison 01 / Total $(\Sigma)$ of column 1 therefore $1 / 16.2=0.0617$ ), resulting in a normalized matrix (Table 4). To acquire the numerical weight of importance of each criterion (eigenvector), the arithmetic mean of each normalized row was found. For example, for the classes of soil criterion, applying Equation 2, the eigenvector $(w)$ was $(0.0617+0.0744+0.1613+0.0431+0.0446) / 5$ $=0.0770$. The result is the vector representing the criteria individually.

Table 3. Pairwise comparison matrix between the study parameters (in parentheses, non-fractionated values). Tabela 3. Matriz de comparação pareada entre os parâmetros do estudo (entre parênteses, valores não fracionados).

\begin{tabular}{c|ccccc}
\hline \multicolumn{5}{c}{ Paired Comparison Matrix } \\
\hline & $\begin{array}{c}\text { Classes of } \\
\text { Soils (CS) }\end{array}$ & $\begin{array}{c}\text { Terrain Slope } \\
\text { (TS) }\end{array}$ & $\begin{array}{c}\text { Geological } \\
\text { Domains (GD) }\end{array}$ & $\begin{array}{c}\text { Rainfall } \\
\text { (R) }\end{array}$ & $\begin{array}{c}\text { Drainage } \\
\text { Hierarchy (DH) }\end{array}$ \\
\hline $\begin{array}{c}\text { Classes of Soils } \\
\text { (CS) } \\
\text { Terrain Slope } \\
\text { (TS) }\end{array}$ & 1 & $1 / 7$ & 5 & $1 / 5$ & $1 / 3$ \\
\cline { 2 - 6 } & 7 & 1 & 9 & 3 & 3 \\
\hline
\end{tabular}




\begin{tabular}{c|ccccc}
\cline { 2 - 6 } $\begin{array}{c}\text { Geological } \\
\text { Domains }(\mathbf{G D})\end{array}$ & $1 / 5$ & $1 / 9$ & 1 & $1 / 9$ & $1 / 7$ \\
\cline { 2 - 6 } Rainfall (R) & 5 & $1 / 3$ & 9 & 1 & 3 \\
\cline { 2 - 6 } $\begin{array}{c}\text { Drainage } \\
\text { Hierarchy }(\mathbf{D H})\end{array}$ & 3 & $1 / 3$ & 7 & $1 / 3$ & 1 \\
\hline Total $\left(\sum\right)$ & 16.2 & 1.9 & 31.0 & 4.6 & 7.5 \\
\hline
\end{tabular}

Table 4. Matrix of Importance Factors calculated and distributed in hierarchical order.

Tabela 4. Matriz de Fatores de Importância calculados, e distribuídos em ordem hierárquica.

\begin{tabular}{c|ccccc|c|c|c|c}
\hline \multicolumn{7}{c|}{ (I) Matrix of Importance Factors } & \multicolumn{2}{c}{ (II) Order of importance } \\
\hline$*$ & CS & TS & GD & R & DH & $\begin{array}{c}\text { Calculated Weight } \\
\text { of Importance }\end{array}$ & Criteria & Weights & $\begin{array}{c}\text { Weights } \\
(\%)\end{array}$ \\
\hline CS & 0.0617 & 0.0744 & 0.1613 & 0.0431 & 0.0446 & 0.0770 & $\mathbf{1}^{\mathbf{0}}-\mathbf{T S}$ & 0.4581 & $45.8 \%$ \\
TS & 0.4321 & 0.5207 & 0.2903 & 0.6459 & 0.4013 & 0.4581 & $\mathbf{2}^{\mathbf{o}}-\mathbf{R}$ & 0.2778 & $27.8 \%$ \\
GD & 0.0123 & 0.0579 & 0.0323 & 0.0239 & 0.0191 & 0.0291 & $\mathbf{3}^{\mathbf{0}}-\mathbf{D H}$ & 0.1580 & $15.8 \%$ \\
R & 0.3086 & 0.1736 & 0.2903 & 0.2153 & 0.4013 & 0.2778 & $\mathbf{4}^{\mathbf{0}}-\mathbf{C S}$ & 0.0770 & $7.7 \%$ \\
DH & 0.1852 & 0.1736 & 0.2258 & 0.0718 & 0.1338 & 0.1580 & $\mathbf{5}^{\mathbf{0}}-\mathbf{G D}$ & 0.0291 & $2.9 \%$ \\
\hline
\end{tabular}

*CS: Classes of Soils; TS: Terrain Slope; GD: Geological Domains; P: Rainfall; DH: Drainage hierarchy.

The terrain slope was a factor of greater relevance in the evaluation of potential environmental fragility in the Jequitinhonha river basin (45.8\% value of importance). Rainfall presented the second level of importance $(27.8 \%)$, and drainage hierarchy presented the third primary importance at $15.8 \%$, due to the predominance of the 1st and 2nd order of drainage channels of $11,058.10 \mathrm{~km}^{2}$, and $5,491.64 \mathrm{~km}^{2}$, respectively. The fourth and fifth criteria are classes of soils, with $7.7 \%$ and geological domains, with $2.9 \%$ of the weights.

The calculated weights of importance consist of the eigenvectors necessary for the next step in calculating the maximum or main eigenvector $(\lambda \max )$. We organized each weight (Table 4$)$ in the hierarchical order of decreasing importance: terrain slope; rainfall; drainage hierarchy; classes of soils; and geological domains in fifth place.

The next step is the verification of the consistency ratio linked to the degree of reliability of the variables. The main pair-wise comparison matrix is consistent if $\lambda_{\operatorname{Max}} \geq \mathrm{n}$ (SAATY, 1980). The calculation matrix for $\lambda_{\text {Max }}$ (Equation 3) is presented in Table 5. As an example, we presented the classes of soil criterion: $[(1 * 0.0770)+$ $(0.143 * 0.4581)+(5 * 0.0291)+(0.2 * 0.2778)+(0.333 * 0.1580)] / 0.0770=5.1444$. From the sum of the means of consistencies, divided by 5 , the main eigenvector found was $\lambda_{\operatorname{Max}}=(5.1444+5.6030+5.1151+5.5844+5.3034)$ / $5=5.35$, which is greater than 5 . Thus, the main weighting matrix is consistent in this study.

Table 5. Calculation of the Principal Eigen ( $\lambda$ Max $)$ - Main eigenvalue.

Tabela 5. Cálculo do Eigen Principal ( $\lambda$ Max $)$ - Autovalor principal.

\begin{tabular}{|c|c|c|c|c|c|c|}
\hline$*$ & CS & TS & GD & $\mathbf{R}$ & DH & Eigenvector \\
\hline CS & 1 & 0.143 & 5 & 0.2 & 0.333 & \multirow{5}{*}{$\begin{array}{l}0.0770 \\
0.4581 \\
0.0291 \\
0.2778 \\
0.1580\end{array}$} \\
\hline TS & 7 & 1 & 9 & 3 & 3 & \\
\hline GD & 0.2 & 0.111 & 1 & 0.111 & 0.143 & \\
\hline $\mathbf{R}$ & 5 & 0.333 & 9 & 1 & 3 & \\
\hline DH & 3 & 0.333 & 7 & 0.333 & 1 & \\
\hline $\begin{array}{l}\text { Average of } \\
\text { consistencies }\end{array}$ & 5.144 & 5.603 & 5.115 & 5.584 & 5.303 & $\begin{array}{c}\text { Main Eigen } \\
\lambda \mathrm{Max}=5.350\end{array}$ \\
\hline
\end{tabular}

*CS: Classes of Soils; TS: Terrain Slope; GD: Geological Domains; R: Rainfall; DH: Drainage Hierarchy.

If the diagonal of the main matrix is numbered with $a_{i j}=1$, and if the matrix is consistent, small variations of $\mathrm{a}_{\mathrm{ij}}$ maintain the eigenvalue $\left(\lambda_{\mathrm{Max}}\right)$ near $\mathrm{n}$, and the remaining eigenvalues (eigenvectors) close to zero (SAATY, 1980). These characteristics corroborate the evaluation of this study, where $\mathrm{a}_{\mathrm{ij}}$ is equal to 1 for all comparisons of the matrix diagonal. In this study, the mean consistencies $\left(\lambda_{\text {Max }}\right)$ presented in Table 5 were close to $n,(\lambda \operatorname{Max},=5.35)$ and $(n=5)$, and the eigenvalues (eigenvector) were close to zero $(* C S=0.0770, T S=0.4581$, $\mathrm{GD}=0.0291, \mathrm{R}=0.2778, \mathrm{DH}=0.1580)$. These characteristics corroborate the consistency of the AHP matrix (SAATY, 1980).

FLORESTA, Curitiba, PR, v. 50, n. 3, p. 1623 - 1632, jul/set 2020.

França, L. C. J. et.al.

ISSN eletrônico 1982-4688 


\section{AHP Consistency Index and Ratio}

The CI was calculated after structuring and normalizing the main comparative matrix, and the value of the eigenvectors as well as the main eigenvector $(\lambda \mathrm{Max})$ was obtained. The $\mathrm{CI}=0.0875$, considering the dimension of the matrix $(\mathrm{n}=5)$, from Equation 4:

$$
C I=\frac{\lambda \operatorname{Max}-n}{n-1} \therefore \frac{(5.3501-5)}{(5-1)}=C I=0.0875
$$

Equation 5 was used to investigate the $\mathrm{CR}$, which derives from the division between the $\mathrm{CI}$ and RI, which is 1.12 , according to Table 2 :

$$
C R=\frac{C I}{R I} \therefore \frac{0.0875}{1.12}=C R=0.0781
$$

The CR found was 0.0781 within acceptable limits (0.1 or 10\%) (SAATY, 1980). The comparisons generated reliable results, confirming that the matrix was filled randomly. The results are suitable for integration into the potential environmental fragility equation in a GIS environment.

\section{DISCUSSION}

The AHP method proved useful for the case study in considering qualitative evaluations as quantitative factors for the decision-making process and reducing the study of complex systems to a sequence of comparisons of pairs of properly identified components (SAATY,1980). That is, its application allows the organization of hierarchically complex problems involving several criteria. It is a flexible process that simultaneously uses mathematics and empirical knowledge of experts on the subject. The method can be considered essentially efficient, given its classic use in studies involving decision-making; presenting itself as a methodology that offers reliable results (SAATY, 2005).

Terrain slope was a factor of greater relevance in the evaluation of potential environmental fragility in the Jequitinhonha river basin. Data from the Paraná state and the Upper Paranaíba region in Minas Gerais, from a pair-wise comparison matrix, also resulted in the highest weight of importance for the slope terrain variable, at approximately $40 \%$ of importance (MIARA; OKA-FIORI, 2007; SILVA et al., 2016). The environmental factors linked to terrain slope are directly related to erosive processes, mass movement, and the favoring of surface runoff of the waters. This is significant in the context of the study area, as it is a region with highly sloping reliefs.

The rainfall factor, with $27.8 \%$ importance value is linked as a passive and active agent in the processes of surface runoff and/or favor erosion. Considering the drainage hierarchy factor is essential to emphasize that the greater the percentage participation of first-order channels, the higher the potential fragility. The first-order drainage indicates greater instability of the environment and represents the sectors of intense morphodynamic processes associated with dissection (TUCKER; HANCOCK, 2010).

The classes of soil factors, with distinct physical and chemical characteristics, submitted to erosive action, related to environmental fragility. However, this criterion presented non-incisive weight (7.7\%), when analyzed together with other multiple factors (ROSS, 1994). It is essential to consider that the soil mapping scales in Brazil are regional, implying imprecise affirmations about the fragilities involved. The geological domain factor had little percentage participation in the AHP analysis $(2.9 \%)$ because it is an element in predominantly static condition when compared to others.

The CR value of 0.0781 was within acceptable limits (0.10), according to Saaty (1980). This demonstrates that the comparisons made were consistent and generated reliable results as well as confirming that the matrix was consistent and did not require restructuring. Other studies of multi-criteria that analyzed environmental fragility using the AHP also reached values considered excellent (SCHIMIDT; BARBOSA, 2016; GONÇALVES et al., 2016) for matrices of comparisons with variables partially similar to those used here, thus attesting to consistency in the data hierarchy.

It is important to note that with the incorporation of new factors related to the determination of the environmental fragility, the results will be more proximate to the local reality (GONÇALVES et al., 2011). This also predicts the importance of each factor as a determining condition for a coherent assessment of environmental fragility (CORTE et al., 2015). Using multi-criteria analysis in GIS and the identification of the importance of criteria, Valente et al. (2017) defined priority areas for forest restoration, assigning actions, and solutions.

In this context, the malleability of the methodology allows the analyst to adopt new factors according to the goals of environmental fragility mapping or other decision-making activities. Since it is a decision-making process in a participatory environment and under the judgment and selection of alternatives under the viewpoints

FLORESTA, Curitiba, PR, v. 50, n. 3, p. 1623 - 1632, jul/set 2020.

França, L. C. J. et.al.

ISSN eletrônico 1982-4688

DOI: $10.5380 /$ rf.v50 i3. 65146 
of different analysts (who may or may not agree), it has precedents as to the value judgment applied to the method. In the application steps, the data entry is relatively simple and based on a paired comparison of the criteria under the logic of binary correlation. However, attention must be paid to the comparative matrix structuration and weights so that there is no tendency or bias on the part of the specialists.

The CI and CR are sensitive and coherent factors in the decision process consisting of the judgments of the leading mathematical matrix (SANTOS; CRUZ, 2013) and allowing for repeated adjustments in the comparison (MARTINS et al., 2014). The toleration limit $<0.1$ or 10 is a questionable constraint due to the margin of error involved, about which there is little discussion in the literature. Some questions are raised regarding the Saaty index, mainly because there is no consensus on the need to evaluate the tolerable margin of error in the consistency assessment. Bana e Costa et al. (2001) present a critique of the coefficient of inconsistency proposed by Saaty.

Considering the advantages and disadvantages of AHP mathematical modeling, which may or may not reduce uncertainties in the decision-making process, it is suggested to complement the AHP approach with operational research and computational programing methods for application to the multiple problems in agrarian and environmental science.

\section{CONCLUSIONS}

- In this study, it was possible to satisfactorily apply the AHP method as a tool to support multi-criteria decisionmaking to define the importance hierarchy of physical and environmental factors that contribute to the potential environmental fragility assessment of the river basin of Rio Jequitinhonha. The procedural steps of the AHP were also described in order to assist other researchers in methodological replication.

- Although data entry for the paired comparison matrix is simple, attention must be paid to the weighting and structuring steps of the comparative matrices, in order to avoid inconsistencies. Recognition of the physical, environmental, and landscape features of the area is essential in any case study.

\section{ACKNOWLEDGMENTS}

The first author thanks the Coordenação de Aperfeiçoamento de Pessoal de Nível Superior - Brasil (CAPES) - Financing Code 001 - for granting the research grant to the Federal University of the Jequitinhonha and Mucuri Valleys (UFVJM) for the period in which the study and the University of Porto had the opportunity. Special thanks to Prof. Dr. Jurandyr Ross (USP), Prof. Dr. Allaoua Saadi (UFMG), and Prof. João Honrado Pradinho (University of Porto) for the scientific contribution in certain stages of this study. The authors thank the anonymous reviewers for their careful reading of our manuscript and their many insightful comments and suggestions.

\section{REFERENCES}

BANA E COSTA, C. A.; VANSNICK, J. C. Une critique de base de l'approche de Saaty: mise en question de la méthode de la valeur propre maximale. Cahier du LAMSADE, Paris, n.178, 2001.

CORTE, A. P. D.; HENTZ, A. M. K.; DOUBRAWA, B.; SANQUETTA, C. R. Environmental fragility of Iguaçu river watershed, Paraná, Brazil. Bosque, Valdivia, v.36, n.2, p. 287-297, 2015.

GONÇALVES, G. G.G.; DANIEL, O.; COMUNELlO, E.; VITORINO, A. C.T.; ARAI, F. K. Determinação da fragilidade ambiental de bacias hidrográficas. Floresta, Curitiba, v.41, n.4, p.797-808, 2011.

GONÇALVES, S. R. A.; ARAÚJO, R. R.; IMAI, N. N. Mapeamento do Grau de Fragilidade com Processo Analítico Hierárquico e operadores Fuzzy Gama na detecção de áreas de fragilidade ambiental. Revista Brasileira de Cartografia, Uberlândia, n.68, ed. 2, p. 327-337, 2016.

IBGE - Instituto Brasileiro de Geografia e Estatística. Diagnóstico ambiental da Bacia do Rio Jequitinhonha: diretrizes gerais para a ordenação territorial. Diretoria de Geociencias: IBGE, Salvador: 64p., 1997. Available in: <https://biblioteca.ibge.gov.br/visualizacao/livros/liv95902.pdf >. Acces in: 23/04/2020.

JÚNIOR, V. S. Q.; CABRAL, J.B.P.; ROCHA, I. R.; BARCELOS, A. A. Uso de geotecnologias na caracterização da fragilidade ambiental da bacia a UHE Foz do Rio Claro (GO). Geofocus, Barcelona, n.15, p. 193-212, 2015.

KHAIRA, A.; DWIVEDI, R.K. A State of the Art Review of Analytical Hierarchy Process. Materials today: proceedings, Kidlington, v.5, p.4029-4035, 2018. 
KOSTLAN, E. Statistical Complexity of Dominant Eigenvector Calculation.: Journal of Complexity, Hawaii, v.7, n.4, p. 371-379, 1990.

KUNDU, S.; KHARE, D.; MONDAL, A. Land use change impact on sub-watersheds priorization by analytical hierarchy process (AHP). Ecological Informatics, Adelaide, v.42, p. 100-113, 2017.

MARTINS, F. C M.; ANDRADE, L. C. R.; CALIJURI, M. L.; BARROS, K. O.; BARRETO, E. M. Multicriteria analysis and geoprocessing for conservation of unpaved roads. Revista de Ciências Agrárias de Portugal, Lisboa, V.37, n.2, p. 162-170, 2014.

MIARA, M. A.; OKA-FIORI, C. Analysis by multiple criteria for the definition of environmental fragility levels - A case study: watershed of Cará-Cará River, Ponta Grossa/PR. RA'EGA, Curitiba, n.13, p.85-98, 2007.

MORANDI, D. T.; FRANÇA, L. C. J.; MENEZES, E. S.; MACHADO, E. L. M.; SILVA, M. D.; MUCIDA, D. P. Delimitation of ecological corridors between conservation units in the Brazilian Cerrado using a GIS and AHP approach. Ecological Indicators, Coimbra, v. 115, p. 106-144, 2020.

PADILHA, D. G.; TREVISA, M. L.; CRUZ, J. C. Sensibilidade do Modelo de Fragilidades Ambientais à Ponderação Multicriterial: Aspectos Físicos da Bacia Hidrográfica do Alto Uruguai. Floresta, Curitiba, v.44, n.3, p.535 - 548, 2014.

ROSA, M. R.; ROSS, J. L. Aplicação de SIG na geração de cartas de fragilidade. Revista do Departamento de Geografia, São Paulo, n. 13, 1999.

ROSS, J. L. S. Análise Empírica da Fragilidade dos Ambientes Naturais e Antropizado. Revista do Departamento de Geografia, São Paulo, n. 8, p.24-30, 1994.

SAATY, T. L. Theory and Applications of the Analytic Network Process: Decision Making with Benefits, Opportunities, Costs, and Risks. Pittsburgh: RWS Publications, 2005.

SAATY, T.L. The Analytic Hierarchy Process. McGraw Hill International, New York, 1980.

SAHOO, S.; DHAR, A.; KAR, A. Environmental vulnerability assessment using Grey Analytic Hierarchy Process based model. Environmental Impact Assessment Review, Norwich, v. 54, p. 145-154, 2016.

SANTOS, L. F.; CRUZ, R. B. C. O uso do método AHP na tomada de decisão para seleção de sistemas de lajes de edifícios comerciais. Eng. Estudo e Pesquisa ABPE, Juiz de Fora, v.13, n.1, p.39-52, 2013.

SILVA, W. G.; MACHADO, V. M.; CHAGAS, M. V. S.; FLORES, W.M.F. Susceptibilidade a erosão utilizando o processo de análise hierárquica (AHP) e sistema de informação geográfica. Cerrado Agrociências, v.7, p.6678, 2016.

SCHIMIDT, M. A. R.; BARBOSA, G. R. Uso de redes neurais artificiais na ponderação inicial da técnica AHP em análises de vulnerabilidade de bacias hidrográficas. Boletim de Ciências Geodésicas, Curitiba, v. 22, n.3, p. 511-525, 2016.

TUCKER, G. E.; HANCOCK, G. R. Modelling landscape evolution. Earth Surface Process and Landsforms, Switzerland, v.35, p.28-50, 2010.

VALENTE, R. A.; PETEAN, F. C. S.; VETTORAZZI, C. A. Multicriteria decision analysis for prioritizing áreas for forest restoration. CERNE, Lavras, v.23, n.1, p. 53-60, 2017.

VALENTE, R. A.; VETTORAZZI, C. A. Comparação entre métodos de análise de sensibilidade, empregados na tomada de decisão com avaliação multicriterial. Scientia Forestalis, São Paulo, v.37, n.82, p.197-211, 2009.

VARGAS, R. V. V. Utilizando a programação multicritério (Analytic Hierarchy Process - AHP) para selecionar e priorizar projetos na gestão de portfólio. PMI Global Congress - North America, EUA, 2010. 